\title{
Some Biological Consequences of the Inhibition of Na,K-ATPase by Translationally Controlled Tumor Protein (TCTP)
}

\author{
Jiwon Jung, Seonhyung Ryu, In A Ki, Hyun Ae Woo * and Kyunglim Lee * \\ Graduate School of Pharmaceutical Sciences, College of Pharmacy, Ewha Womans University, Seoul 120-750, \\ Korea; major87@hanmail.net (J.J.); shryu8723@gmail.com (S.R.); inainakee@gmail.com (I.A.K.) \\ * Correspondence: hawoo@ewha.ac.kr (H.A.W.); klyoon@ewha.ac.kr (K.L.); \\ Tel.: +82-2-3277-4654 (H.A.W.); +82-2-3277-3024 (K.L.); Fax: +82-2-3277-2851 (K.L.)
}

Received: 5 April 2018; Accepted: 30 May 2018; Published: 4 June 2018

\begin{abstract}
Na}, \mathrm{K}-\mathrm{ATPase}$ is an ionic pump that regulates the osmotic equilibrium and membrane potential of cells and also functions as a signal transducer. The interaction of $\mathrm{Na}, \mathrm{K}$-ATPase with translationally controlled tumor protein (TCTP) results, among others, in the inhibition of the former's pump activity and in the initiation of manifold biological and pathological phenomena. These phenomena include hypertension and cataract development in TCTP-overexpressing transgenic mice, as well as the induction of tumorigenesis signaling pathways and the activation of Src that ultimately leads to cell proliferation and migration. This review attempts to collate the biological effects of $\mathrm{Na}$,K-ATPase and TCTP interaction and suggests that this interaction has the potential to serve as a possible therapeutic target for selected diseases.
\end{abstract}

Keywords: autophagy; hypertension; $\mathrm{Na}, \mathrm{K}-\mathrm{ATPase}$; translationally controlled tumor protein; tumorigenesis

\section{Introduction}

$\mathrm{Na}, \mathrm{K}$-ATPase is a P-Type ATPase that acts as an ionic pump that helps to maintain osmotic equilibrium and membrane potential in cells. $\mathrm{Na}, \mathrm{K}$-ATPase has been the subject of numerous studies since its discovery as an ion pump [1]. The ionic and electrochemical gradients maintained by $\mathrm{Na}, \mathrm{K}-\mathrm{ATPase}$ play critical roles in numerous physiological processes, such as electrical excitability, ion reabsorption in kidney, regulation of cell volume, uptake of nutrients into the cell, and regulation of cardiac glycoside (CG)-mediated signaling pathways [2-4].

$\mathrm{Na}$,K-ATPase interacts with translationally controlled tumor protein (TCTP), also known as TPT1, P23, fortilin, and histamine-releasing factor, a highly conserved protein, ubiquitous in multicellular organism [5], and is itself involved in the regulation of many fundamental processes, such as cell proliferation, apoptosis, autophagy, pluripotency, progression of the cell cycle, and cytokine-like activity [6] to promote manifold biological and pathological phenomena. This review attempts to present current information on these biological phenomena.

\section{Na,K-ATPase, TCTP, and Their Interaction}

\section{1. $\mathrm{Na}, \mathrm{K}$-ATPase}

$\mathrm{Na}, \mathrm{K}-\mathrm{ATPa} e$ is a multi-subunit plasma membrane protein of P-type ATPases, which transport cations across the cell membrane. Using energy from ATP, the conformational transition of the $\alpha$ subunit couples the processes of phosphorylation and extrusion of three $\mathrm{Na}^{+}$ions with the uptake of two $\mathrm{K}^{+}$ions [7]. Na,K-ATPase plays an essential role in maintaining an electrochemical gradient across 
the cell membrane. The established ionic and electrochemical gradient plays critical roles in numerous physiological processes, such as electrical excitability, ion reabsorption in kidney, regulation of cell volume and osmotic pressure, and uptake of nutrients into the cell [8].

$\mathrm{Na}, \mathrm{K}-\mathrm{ATPase}$ consists of a catalytic $\alpha$ subunit and regulatory $\beta$ and $\gamma$ subunits [9]. Its $110 \mathrm{kDa} \alpha$ subunit is a binding site for ATP, cations, and cardiac glycosides and is composed of 10 transmembrane (TM) domains and three major cytoplasmic domains [10]. The Na,K-ATPase $\alpha$ subunit has four isoforms, which are distributed differently in different tissues [11]. The $\alpha 1$ isoform is found in all cells, mainly acting as a "housekeeping" isoform. The $\alpha 2$ isoforms are present in muscle, heart, glial cells, and adipocytes. The $\alpha 3$ isoforms are abundant in nervous tissues and skeletal muscle. The $\alpha 4$ subunits are distributed in the testis [12]. The $N$-glycosylated $55 \mathrm{kDa} \beta$ subunit is composed of one transmembrane (TM) helix and acts as a chaperone protein in association with the $\mathrm{Na}, \mathrm{K}-\mathrm{ATPase} \alpha$ subunit, which traffics the $\alpha \beta$ heterodimer to the plasma membrane. The $\beta$ subunit influences $\mathrm{K}^{+}$ion binding affinity to $\mathrm{Na}, \mathrm{K}-\mathrm{ATP}$ ase and plays an essential role in cell polarity $[13,14]$. The $\beta$ isoforms are distributed tissue-dependently. $\beta 1$ is ubiquitously expressed in all tissues. $\beta 2$ was originally found as an adhesion molecule on glial cells mediating neuron and glia interactions and known to promote neurite outgrowth. $\beta 2$ is also found in neurons, pineal gland, and skeletal muscle. $\beta 3$ is primarily distributed in the testis, but also found in glial cells, liver, lung, and kidney. The $\alpha 1 \beta 1$ isoform is the main $\mathrm{Na}, \mathrm{K}-\mathrm{ATPase}$ isozyme, which provides the driving force for $\mathrm{Na}^{+}$reabsorption. Diverse $\alpha$ and $\beta$ isozyme combinations are present depending on the tissues and cell types [12]. The $\gamma$-subunit, often known as FXYD2 protein, is mainly expressed in the kidney. It interacts with $\mathrm{Na}, \mathrm{K}$-ATPase $\alpha \beta$ heterodimers in a tissue-specific manner and modulates the activity of $\mathrm{Na}, \mathrm{K}$-ATPase by regulating ion channel activity [15].

Since $\mathrm{Na}$,K-ATPase is important for maintaining various cellular functions, its inhibition could result in diverse pathologic states. Inhibition of $\mathrm{Na}, \mathrm{K}$-ATPase causes high intracellular $\mathrm{Na}^{+}$ion levels and subsequent increases in intracellular $\mathrm{Ca}^{2+}$ ion through the $\mathrm{Na}^{+} / \mathrm{Ca}^{2+}$ exchanger [16]. Cardiac glycosides such as ouabain inhibit $\mathrm{Na}, \mathrm{K}-\mathrm{ATP}$ ase and elevate the intracellular $\mathrm{Ca}^{2+}$ ion level, causing hypertension, cataracts, diabetes, and several other pathological events [17-19]. Recently, the activation of several signaling pathways by low-dose ouabain was identified without alteration in intracellular ionic concentration [8]. Inhibition of $\mathrm{Na}, \mathrm{K}$-ATPase by ouabain induced the activation of epidermal growth factor receptor (EGFR) in A7r5 and LLC-PK1 cells, leading to the identification of Src kinase as a key player in $\mathrm{Na}$,K-ATPase signal transduction [20]. Several signaling pathways, such as Ras-Raf-MEK-MAPK, phospholipase- $\gamma$ (PLC- $\gamma$ ), and phosphatidylinositide 3-kinase (PI3K) pathways have been identified as downstream signaling pathways of ouabain-induced Src kinase activation. These activated signaling pathways are involved in modulating gene expression related to cell growth, survival, and motility [21-23]. The diverse functions of $\mathrm{Na}, \mathrm{K}-\mathrm{ATP}$ ase as a signal transducer as well as an ion transporter are still currently being investigated.

\subsection{Translationally Controlled Tumor Protein (TCTP)}

TCTP is a ubiquitous multifunctional protein first discovered in mouse sarcoma ascites cells [24]. TCTP has been implicated in many biological processes, such as cell growth [25], microtubule stabilization [26], allergic reaction [27], tumor reversion [28], and tumorigenesis [29]. One of its important function is its role in tumorigenesis. TCTP level in tumors is higher than in the corresponding normal tissues [30], and TCTP downregulation induced tumor reversion in diverse cancer cell lines [28]. TCTP has been reported to promote cell migration and invasion by inducing epithelial to mesenchymal transition (EMT) in LLC-PK1 cells [31]. Another important function of TCTP is its extracellular role as a histamine-releasing factor [27] which acquires cytokine-like function by dimerization [32]. Also, its importance in cell survival was discovered in TCTP-knockout mice, in which it was embryonic lethal at 6.5 day as a consequence of increased cell death [33].

TCTP interaction with different binding partners produces diverse biological effects (Table 1). TCTP interacts with Bcl-xL [34] and Mcl-1 [35] and increases their stability, thereby providing 
anti-apoptotic effects. By interacting with heat shock protein 27 (Hsp27), a protein highly overexpressed in castration-resistance prostate cancer (CRPC), TCTP mediates Hsp27-induced cytoprotection in CRPC cells [36]. TCTP also interacts with p53 and inhibits p53-induced transcriptional activation of Bax [37], and p53 and TCTP are known to act as reciprocal regulators [38]. TCTP also interacts with MDM2 and inhibits ubiquitination of MDM2, inducing p53 degradation [39]. Polo-like kinase interacts and phosphorylates TCTP, thereby decreasing the microtubule-stabilizing effect of TCTP [26]. It has been shown that TCTP interaction with $\mathrm{Na}$,K-ATPase occurs via the third cytoplasmic domain of $\mathrm{Na}$,K-ATPase $\alpha$ subunit and inhibits the latter's pumping activity, leading to a pathological phenotype in TCTP-overexpressing transgenic mice [40,41]. Clearly, all these interactions involving TCTP are important and still need to be better understood and explained. Our laboratory has long been interested in the interaction of TCTP with Na,K-ATPase and has made some important contributions to the topic. This review covers only the interaction of TCTP with Na,K-ATPase, summarizing what is currently known on the interaction and its biological implications.

Table 1. Translationally controlled tumor protein (TCTP) interacting partners.

\begin{tabular}{llll}
\hline Interacting Partners & Array & Significance & Reference \\
\hline Bcl-xL & IP, Pull-down & $\begin{array}{l}\text { The N-terminal region of TCTP interacts with Bcl-xL } \\
\text { and increases stability of Bcl-xL }\end{array}$ & {$[34]$} \\
\hline eEF1B & Crystallography, MS & $\begin{array}{l}\text { TCTP interacts with the central acidic region } \\
\text { of eEF1B }\end{array}$ & {$[42]$} \\
\hline Hsp27 & Yeast two-hybrid, IP & $\begin{array}{l}\text { Hsp27 interacts with TCTP and protects TCTP from } \\
\text { ubiquitination. }\end{array}$ & {$[43]$} \\
\hline Mcl-1 & Yeast two-hybrid, & $\begin{array}{l}\text { Interaction between TCTP and Mcl-1 increases the } \\
\text { stability of the two proteins }\end{array}$ & {$[35,44]$} \\
\hline PDM2 & Pull-down, IP & $\begin{array}{l}\text { TCTP interacts with the N-terminal region of MDM2 } \\
\text { and inhibits ubiquitination of MDM2 }\end{array}$ & {$[39]$} \\
\hline Yeast two-hybrid, & $\begin{array}{l}\text { TCTP interacts with the third cytoplasmid domain of } \\
\text { Na,K-ATPase } \alpha \text { subunit and inhibits its pumping } \\
\text { activity. TCTP induces Na,K-ATPase-mediated } \\
\text { tumorigenic signaling pathways }\end{array}$ & {$[29,45]$} \\
\hline Pull-down, IP & IP, Pull-down & $\begin{array}{l}\text { TCTP forms a complex with p53 and MDM2 and } \\
\text { promotes the degradation of p53 }\end{array}$ & {$[38]$} \\
\hline Plk & Pull-down, IP & $\begin{array}{l}\text { Plk interacts and phosphorylates TCTP, inhibiting } \\
\text { the microtubule-stabilizing activity of TCTP }\end{array}$ & {$[26]$} \\
\hline Tubulin & IP, Pull-down & $\begin{array}{l}\text { TCTP interacts with tubulin during most of the cell } \\
\text { cycle phases (G1, S, G2, and early M phase) and not } \\
\text { during the resting state }\end{array}$ & {$[34,46]$} \\
\hline
\end{tabular}

\footnotetext{
Arrays: IP, immunoprecipitation; MS, mass spectrometry; eEF1B, eukaryotic elongation factor 1B; Hsp27, heat shock protein 27; Mcl-1, myeloid cell leukemia 1 protein; MDM2, mouse double-minute 2 homolog; Plk, polo-like kinase; VHL, von Hippel-Lindau protein.
}

\section{Na,K-ATPase-TCTP Interaction in Molecular Terms}

TCTP acts as a cytoplasmic repressor of $\mathrm{Na}, \mathrm{K}-\mathrm{ATPase}$ by interacting with its third cytoplasmic domain. TCTP interaction with Na,K-ATPase $\alpha 1$ and $\alpha 2$ subunits was first discovered using the yeast-two hybrid system [45] and then confirmed by co-immunoprecipitation assays in HeLa [49] and MCF10A cells [29]. The third cytoplasmic domain of Na,K-ATPase $\alpha$ subunit was fused to the LexA DNA-binding domain and was used to isolate several cDNA clones from a rat skeletal muscle library, one of which was later identified as TCTP. Using yeast and mammalian cells, the C-terminal region of TCTP was discovered to be essential for the interaction with and inhibition of $\mathrm{Na}$,K-ATPase. TCTP 
binding to $\mathrm{Na}, \mathrm{K}$-ATPase inhibited its pumping activity without decreasing its mRNA and protein level [45].

The conformational changes in Na,K-ATPase $\alpha$ subunit resulting from the interaction with TCTP affected the binding of PI3K and Src to Na,K-ATPase [29]. PI3K is known to interact with the N-terminal proline-rich motif of $\mathrm{Na}, \mathrm{K}-\mathrm{ATPase} \alpha$ subunit [50], and PI3K p85 protein is released and activated after TCTP overexpression [29]. It is reported that the SH3-SH2 domain of Src interacts with the second cytoplasmic domain of $\mathrm{Na}, \mathrm{K}$-ATPase $\alpha 1$, and the kinase domain of Src interacts with the third cytoplasmic domain of Na,K-ATPase $\alpha 1$. After ouabain treatment, the SH3-SH2 domain of Src remains bound to $\mathrm{Na}, \mathrm{K}$-ATPase $\alpha 1$, and only the kinase domain of Src is exposed to induce signaling pathways [51]. Unlike the ouabain-induced $\mathrm{Na}$,K-ATPase signaling pathway which only exposes Src kinase domain [51], TCTP overexpression releases Src from Na,K-ATPase and phosphorylates Src Tyr 418 residue in human breast epithelial cell, thus activating a Na,K-ATPase-induced tumorigenic signaling pathway [29].

\section{Diverse Biological and Pathological Effects of Na,K-ATPase-TCTP Interaction}

\subsection{Na,K-ATPase Inhibition by TCTP Is Implicated in Hypertension and Cataracts in Mice}

In order to investigate the biological effects of Na,K-ATPase-TCTP interaction, Kim et al. [40,41] generated TСТР-overexpressing transgenic mice with different backgrounds using the chicken $\beta$-actin promoter: one type of transgenics in the C57BL/ 6 background and another type in the C57BL/6+ CBA hybrid background which were backcrossed with C57BL/ 6 mice. TCTP-induced Na,K-ATPase inhibition in both types of TCTP-overexpressing transgenic mice led to systemic arterial hypertension as early as six weeks after birth, with no significant cardiac dysfunction (Figure 1) [40,41]. Na,K-ATPase is a key molecule that controls cellular ion homeostasis [8] and regulates smooth muscle contractility in the vasculature [52,53]. The inhibition of $\mathrm{Na}, \mathrm{K}-\mathrm{ATP}$ ase by ouabain [54] and by endogenous ouabain-like compounds [55] is implicated in the development of hypertension. Likewise, the vascular smooth muscle cells of TCTP-overexpressing transgenic mice showed increased sensitivity to vasoconstrictors such as norepinephrine and serotonin, increased $\mathrm{Ca}^{2+}$ levels at resting state, and increased intracellular calcium mobilization, which all ultimately led to an augmented contractile response to vasoconstrictors and an attenuated relaxation response to vasodilators (Figure 1) [40]. One of the explanations for the increased $\mathrm{Ca}^{2+}$ levels following TCTP inhibition of Na,K-ATPase invoked the involvement of a Na${ }^{+} / \mathrm{Ca}^{2+}$ exchanger, which works in reversal mode, pumping out $\mathrm{Na}^{+}$and pumping in $\mathrm{Ca}^{2+}[56]$. Apolipoprotein $\mathrm{E}$ is an important glycoprotein that acts as a ligand for chylomicron-remnant receptor, and lack of apolipoprotein $\mathrm{E}$ is known to induce atherosclerosis in mice [57]. TCTP overexpression in apolipoprotein E knockout mice exacerbated the atherosclerotic lesions, suggesting that the overexpression of TCTP accelerates the development of atherosclerotic lesions caused by a high-fat diet without significantly altering plasma lipid profiles [58].

$\mathrm{Na}, \mathrm{K}-\mathrm{ATPase}$ is critical for the regulation of $\mathrm{Na}^{+}$and $\mathrm{K}^{+}$levels in the lens [59]. In human age-related cortical cataract lens as well as in diabetic cataract lens, $\mathrm{Na}^{+}$levels are abnormally elevated, while $\mathrm{K}^{+}$ levels are abnormally lowered, suggesting a disturbed ion and fluid homeostasis. This disturbance is known to decrease the transparency of the lens causing cataractogenesis [60,61]. Also, fluid accumulation and cellular or protein damage from the activation of calcium-dependent proteases are reported to induce opacification of the lens [62]. Since TCTP, as a cytoplasmic repressor of Na,K-ATPase [45], is known to increase intracellular calcium levels [40], Kim et al. investigated whether opacification of the lens is common in TCTP-overexpressing transgenic C57BL/ $6 \mathrm{~N}$ mice and confirmed that TCTP inhibition of $\mathrm{Na}, \mathrm{K}$-ATPase led to a higher incidence $(7.38 \%)$ of cataracts in TCTP transgenic mice than in the controls $(1.47 \%)$ (Figure 1). A transient overexpression of TCTP inhibited the pumping activity of Na,K-ATPase without affecting its expression level and caused increased $\mathrm{Ca}^{2+}$ mobilization in lens epithelial cells [41]. It is reported that intracellular $\mathrm{Ca}^{2+}$ accumulation induces the activation of proteolytic enzymes, loss of cellular integrity, and apoptosis of cells, which lead to lens opacification [63]. The incidence rate of cataract 
formation was increased only in transgenic C57BL/ $6 \mathrm{~N}$ mice but not in transgenic C57BL/6 + CBA hybrid mice, which acquired systolic hypertension but showed resistance to cataract formation for yet unknown reasons. However, since the incidence of hypertension is known to be associated with cataract formation in humans [64], the pathological phenotype of TCTP-overexpressing transgenic mice, hypertension, and cataractogenesis may occur as a consequence of the pathologic effects of $\mathrm{Na}$, K-ATPase inhibition.
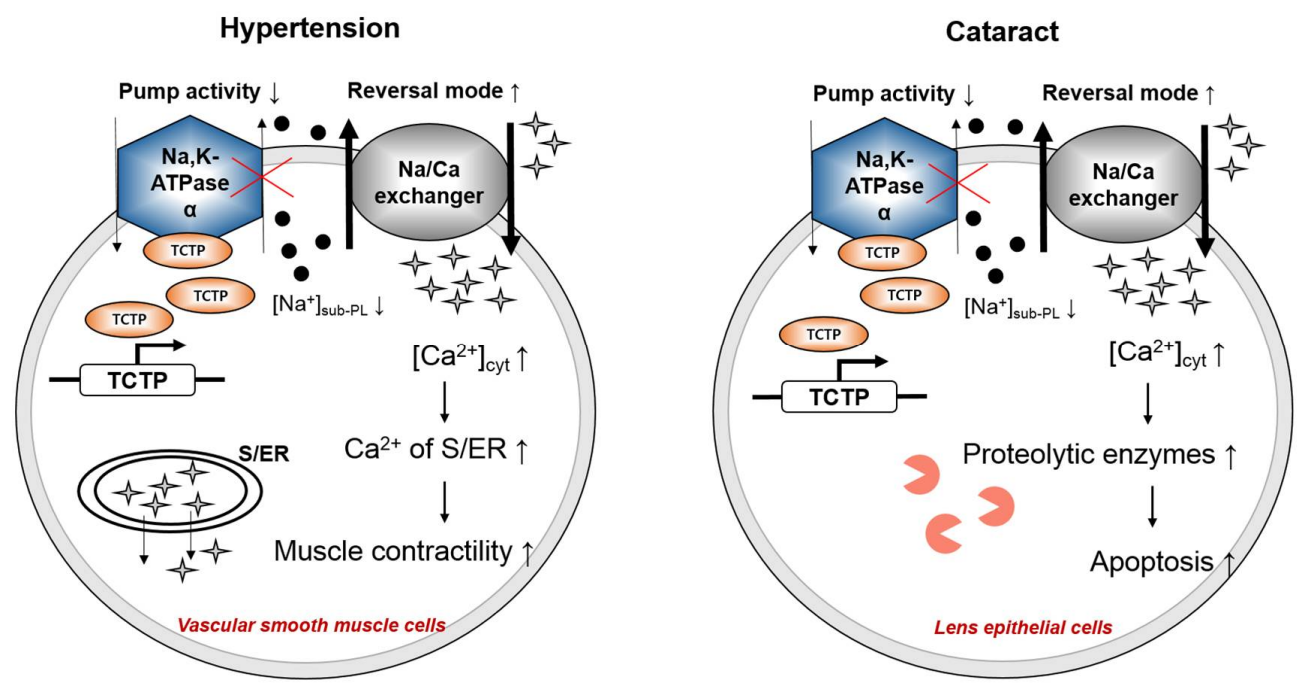

Figure 1. Mechanisms behind hypertension and cataract in TCTP-overexpressing transgenic mice. Systemic arterial hypertension and cataract are induced through the inhibition of $\mathrm{Na}, \mathrm{K}$-ATPase, which leads to accumulation of $\mathrm{Na}^{+}$and increase in cytoplasmic $\mathrm{Ca}^{2+}$ mobilization. Increased $\mathrm{Ca}^{2+}$ levels in sarcoplasmic reticulum and endoplasmic reticulum(S/ER) cause an increase in vascular smooth muscle contractility, inducing hypertension. In lens epithelial cells, the increased $\mathrm{Ca}^{2+}$ mobilization activates proteolytic enzymes that cause apoptosis and cataract. $\left(\mathrm{O}, \mathrm{Na}^{+} ; \mathrm{Ca}^{2+} ; \mathrm{P}\right.$, proteolytic enzymes).

\subsection{Role of $\mathrm{Na}, \mathrm{K}$-ATPase-TCTP Interaction in Tumorigenesis}

TCTP is involved in tumorigenesis $[65,66]$, and various studies demonstrated its anti-apoptotic activity [67]. Na,K-ATPase is known not only for its pumping activity, but also for its signaling activity [68]. TCTP-induced Na,K-ATPase inhibition activates the signal transducing role of $\mathrm{Na}, \mathrm{K}$-ATPase (Figure 2) [29]. Kim et al. demonstrated that TCTP overexpression in HeLa cells inhibits the pumping activity of Na,K-ATPase and induces the phosphorylation of EGFR at Tyr 845, 992, 1068, and 1148 [49]. The key molecule that induces EGFR activation after TCTP overexpression was discovered to be Src. Src kinase directly phosphorylates EGFR at Tyr 845 [69] and promotes cell adhesion, motility, and cancer development [70]. In TCTP-overexpressing MCF10A cells, TCTP interaction with $\alpha 1$ subunit of Na,K-ATPase released and activated Src [29]. EGFR was not activated in TCTP-overexpressing Src-deficient mouse embryonic fibroblasts (SYF), and addition of Src caused the phosphorylation of EGFR at Tyr 845. Activated Src induced EGFR phosphorylation at Tyr 845, 992, 1086, 1148, and 1173 in MCF10A cells. The differences in the phosphorylation of the tyrosine residues of EGFR of HeLa and MCF10A cells may due to differences in the cell lines, but tyrosine 845 of EGFR was activated in both cell lines, suggesting the importance of Src activation in TCTP-induced EGFR transactivation and stimulation of cancer-related signaling pathways.

Different signaling pathways of EGFR are mediated through binding of adaptor proteins [71]. Grb2 is located in the cytosol, constitutively bound to the Ras exchange factor Sos. Phosphorylation at EGFR Tyr 1068 and 1086 recruits Grb2 and Shc adaptor molecules [72] and activates Ras, by exchanging Ras-bound guanosine diphosphate (GDP) to guanosine triphosphate (GTP) [73], and the Ras-Raf-ERK signaling pathway. Likewise, TCTP-induced EGFR activation increases the binding of Grb2, Gab1, and Shc adaptor proteins to EGFR and activates Ras-dependent downstream 
signaling molecules such as Raf, MEK, and ERK1/2 in TCTP-overexpressing MCF10A cells [29]. In TCTP-overexpressing HeLa cells, Ras activity is increased, and ERK1/2 are activated; the activation of both pathways is diminished after treatment with the tyrosine kinase inhibitor genistein and the MEK inhibitor PD98059 [50], suggesting that the Ras-Raf-MEK-ERK1/2 pathway functions downstream of TCTP-induced EGFR transactivation.

Along with the Ras-Raf-MEK-Erk1/2 cascade, the Rac-MKK3/6-p38, PAK1/2 and Rac-PI3K-AKT pathways are activated upon TCTP overexpression [29]. MKK3/6 and p38 phosphorylation was lower compared to Rac activation, which increases markedly in TCTP-overexpressing MCF10A cells. p21-activated kinases (PAK) are serine/threonine kinases that induce cytoskeletal remodeling, cell motility, cell proliferation, and mitotic abnormalities, all of which promote tumor formation [74]. Parallel with Rac activation, PAK1/2 are also activated in TCTP-overexpressing MCF10A cells. The Rac-PI3K-AKT pathway in MCF10A and HeLa cells was also activated after TCTP overexpression. The anti-apoptotic effect of TCTP was dependent on the activation of AKT, which was abrogated by the PI3K inhibitor LY294002 [50]. In addition, TCTP overexpression stimulated reactive oxygen species (ROS) production by NADPH oxidase through Src and PI3K activation [29].
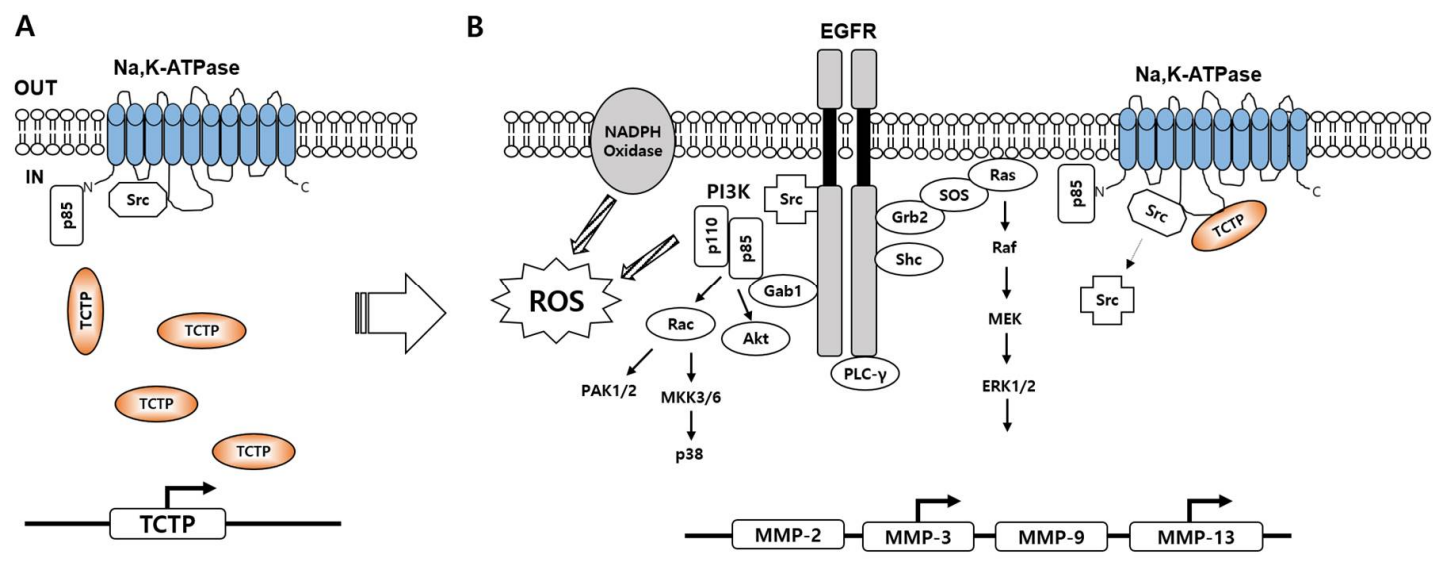

Figure 2. A schematic overview of TCTP-induced Na,K-ATPase signaling pathways. (A) PI3K p85 subunit and Src are constitutively bound to Na,K-ATPase $\alpha$ subunit in the normal state; (B) When TCTP is overexpressed, TCTP interacts with $\mathrm{Na}, \mathrm{K}$-ATPase $\alpha$ subunit and induces $\mathrm{Na}, \mathrm{K}$-ATPase conformational changes that result in Src and p85 release. Activated Src transactivates PI3K-AKT, Ras-Raf-MEK-ERK1/2, Rac-PAK1/2, MKK3/6-p38 and phospholipase C (PLC)- $\gamma$ signaling pathways. TCTP enhances NADPH oxidase-dependent reactive oxygen species (ROS) and induces matrix metalloproteinase (MMP)-3 and -13 .

\subsection{Role of Na,K-ATPase-TCTP Interaction in Cell Migration and Matrix Metalloproteinase (MMP) Upregulation}

TCTP-induced phosphorylation of EGFR at Tyr 992 activated PLC- $\gamma$ [29], which is a key molecular switch that regulates tumor migration [75]. PP2, LY29002, and U73122, which are a Src inhibitor, PI3K inhibitor, and PLC- $\gamma$ inhibitor, respectively, blocked cell motility in TCTP-overexpressing MCF10A cells, indicating the importance of Src, PI3K. and PLC- $\gamma$ activation in TCTP-induced cell migration. Also, TCTP-induced cell migration in HeLa cells was blocked by LY294002, a PI3K inhibitor, but not by U0126, a MEK inhibitor, demonstrating that TCTP-induced cell migration is dependent on the PLC- $\gamma$ pathway, but not on the MAPK pathway [50]. The above findings underscore the importance of the PLC- $\gamma$ pathway in TCTP-induced cell migration.

Matrix metalloproteinases (MMPs) are endoproteinases that function in extracellular matrix degradation [76]. Abnormal MMP expression promotes tumor growth, invasion, and metastasis [77]. TCTP-overexpressing MCF10A cells showed upregulated MMP-3 and MMP-13 [29], and both MMPs 
serve as tumor promoters [78,79]. In TCTP-upregulated LLC-PK1 cells, MMP-9, which is known to be involved in cell invasion, was increased [31]. Since the MAPK signaling pathway activates AP-1 proteins, such as c-jun and c-fos, which promote transcription of MMPs [80], TCTP overexpression likely promotes the expression of MMPs through the activation of the MAPK signaling pathway. The difference in the subtypes of MMPs involved in invasion may be due to differences in the cell lines; however, the results underscore MMPs involvement in TCTP-induced cell invasion.

\subsection{Other Biological Phenomenon in Which Na,K-ATPase Inhibition by TCTP May Possibly Play Role}

Macroautophagy (also referred to as autophagy) is a catabolic process in which proteins and organelles are engulfed by a membrane structure called phagophore, which elongates to form a double-membrane vesicle called autophagosome. Autophagy is involved in a variety of cellular functions, including the nutrient sensing response, cell growth, homeostasis, and cell death [81]. Autophagy is a dynamic process that can be divided into three consecutive processes: formation of autophagosomes, generation of autolysosome, and degradation [82]. Class III PI3K activates AKT and induces mTOR activation that inhibits autophagy [83], and TCTP is known to induce the activation of PI3K by inhibition of Na,K-ATPase [29]. Thus, TCTP involvement in autophagy was investigated by our research group, and it was discovered that TCTP negatively regulates autophagy in vitro and in vivo [84].

\subsubsection{TCTP Downregulation Interrupts BECN1 Interactome}

In HeLa cells, TCTP was reported to interact with Na,K-ATPase and inhibit its pumping activity [46]; also, TCTP inhibition using TCTP siRNA caused activation of Na,K-ATPase, suggesting that endogenous TCTP inhibits Na,K-ATPase activity [85]. Since some reports were published describing how Na,K-ATPase inhibition by cardiac glycosides induces autophagy in various cells [86], our group investigated whether TCTP, a cytoplasmic Na,K-ATPase inhibitor, regulates autophagy. In TCTP-silenced HeLa cells and mouse embryonic fibroblast cells from TCTP heterozygote knockout mice $\left(\mathrm{TCTP}^{+/-}\right.$), the number of GFP-LC3 puncta and lipid-bound GFP-LC3-II level increased, while SQSTM1 level decreased [84]. LC3B-I is converted to LC3B-II by Atg3, and LC3B-II is located on both internal and external surfaces of the autophagosome, helping to select cargoes for degradation [82]. Also, SQSTM1 is an ubiquitin-binding scaffold protein that binds directly to LC3 and recruits protein aggregates to the autophagosome, which are then degraded by autophagic flux [87]. Thus, the increase in the number of GFP-LC3 puncta and the decrease in SQSTM1 level indicated autophagy induction [88], which could be observed in TCTP downregulated cells.

The interaction of BECN1 and class III PI3K induces vesicle nucleation in autophagy; BCL2 is an anti-apoptotic protein that binds to BECN1 and inhibits the interaction between BECN1 and class III PI3K, ultimately repressing autophagy [89]. TCTP-downregulated cells showed decreased BCL2 expression caused by increasing mitogen-activated protein kinase 8 (MAPK8) expression and phosphorylation [84]. MAPK8-JNK1 phosphorylates BCL2, which leads to BCL2 degradation during starvation, resulting in decreased interaction between BECN1 and BCL2 [90]. Since BECN1 expression level of TCTP-downregulated cells did not change, TCTP affects BCL2 by regulating MAPK8-JNK1 activity. The interaction of the catalytic subunit of PI3K and UV radiation resistance-associated gene protein (UVRAG) with BECN1 were significantly increased in TCTP knockdown HeLa cells [84]. BECN1 interaction with class III PI3K initiated vesicle nucleation, and UVRAG addition induced autophagosome formation and maturation [91]. Thus a reduction in TCTP expression stimulates both autophagosome formation and maturation by regulating BECN1 interactome; in other words, TCTP knockdown stimulates the on-rate of autophagy.

\subsubsection{TCTP Inhibition Induces Cellular Autophagy via the mTORC1 and AMPK Pathway}

TCTP downregulation induces cellular autophagy via mTORC1 and adenosine monophosphateactivated protein kinase (AMPK) pathways. It has been reported that TCTP activates mTORC1 
pathway by promoting the GDP-GTP exchange of Rheb [25,92]. In TCTP-downregulated HeLa cells, the phosphorylation levels of ribosomal protein $\mathrm{S6}$ kinase (p70S6 kinase), eukaryotic initiation factor 4E-binding protein 1 (4E-BP1), and ULK1 Ser757, which are all mTORC1 downstream signaling molecules, are decreased, and the total expression level of mTOR is also reduced [84]. Rapamycin induces autophagy by acting as an allosteric inhibitor of mTORC1 [93]. In accordance with the report describing partial rapamycin resistance in the 4E-BP1-eIF4E effector pathway [94], rapamycin treatment alone only partially inhibited 4E-BP1 and p70S6 kinase in HeLa cells [84]. TCTP knockdown synergized with rapamycin-induced autophagy by further dephosphorylating p70S6 kinase and 4E-BP1 and reducing total mTOR expression, suggesting that TCTP-mediated inhibition of autophagy occurs in part through a rapamycin-independent pathway [84]. Furthermore, TCTP downregulation induced autophagy by phosphorylating AMPK $\alpha$ Thr172 under normoxic conditions [95]. TCTP downregulation activates AMPK, which induces phosphorylation of acetyl-CoA carboxylase, a downstream molecule of the AMPK pathway [84]. In contrast, TCTP knockdown did not potentiate starvation-induced autophagy [84] and, rather, inhibited autophagy in starvation or hypoxic condition by inhibiting the phosphorylation of AMPK $\alpha$ Thr172 [95]. Thus, TCTP regulates the mTORC1 and AMPK pathwas in various conditions, functioning as an autophagy regulator.

TCTP functions to inhibit autophagy by controlling mTORC1-independent pathways like MAPK8-BCL2-BECN1, whereas downregulation of TCTP enhances rapamycin-induced autophagy through the inhibition of the mTORC1 pathway and the activation of the AMPK pathway (Figure 3). Thus, TCTP knockdown induces autophagy through both mTORC1-dependent and mTORC1-independent pathways.

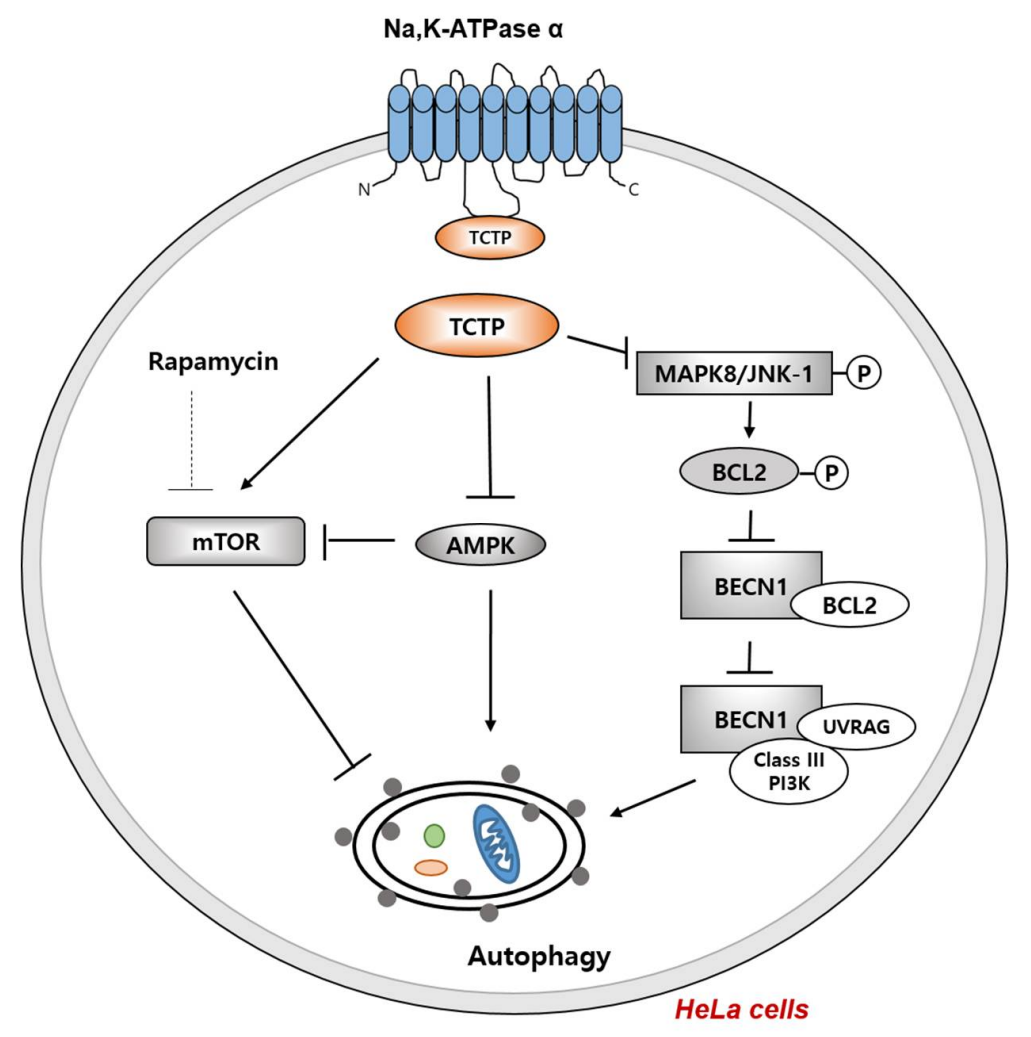

Figure 3. TCTP as a negative regulator of autophagy. TCTP negatively regulates AMPK, which leads to mTORC1 activation that promotes cell proliferation and inhibits autophagy in HeLa cells. TCTP also inhibits MAPK8-JNK1 which is known to phosphorylate and degrade BCL2. BCL2 forms a complex with BECN1 in the normal state, inhibiting autophagy. Once BCL2 is phosphorylated and degraded upon stress or starvation, BECN1 forms a complex with class III PI3K and UV radiation resistance-associated gene (UVRAG) and induces autophagy. 


\section{Concluding Remarks}

This review attempts to explain the manifold functions of TCTP and Na,K-ATPase interaction in various biological phenomena, including tumorigenesis. Several studies have demonstrated that TCTP inhibits $\mathrm{Na}$,K-ATPase by binding to its third cytoplasmic domain and induces pathophysiological events such as hypertension and cataractogenesis in TCTP-overexpressing transgenic mice. The novel function of TCTP in hypertension has been explained as due to its interaction with and inhibition of $\mathrm{Na}, \mathrm{K}$-ATPase. TCTP has been implicated in cancer development in numerous researches, but its exact role in tumor progression has not been understood until the discovery of its interaction with $\mathrm{Na}, \mathrm{K}-\mathrm{ATPa}$ e. Thus, the hypertensive, cancer-related, and other functions of Na,K-ATPase-TCTP interaction reviewed here suggest that TCTP interaction with Na,K-ATPase might represent a potential therapeutic target in selected diseases.

Author Contributions: J.J. and K.L. conceived and designed the review; J.J., S.R. and I.A.K. performed the literary search and wrote the paper; H.A.W. and K.L. reviewed the article.

Conflicts of Interest: The authors declare no conflict of interest.

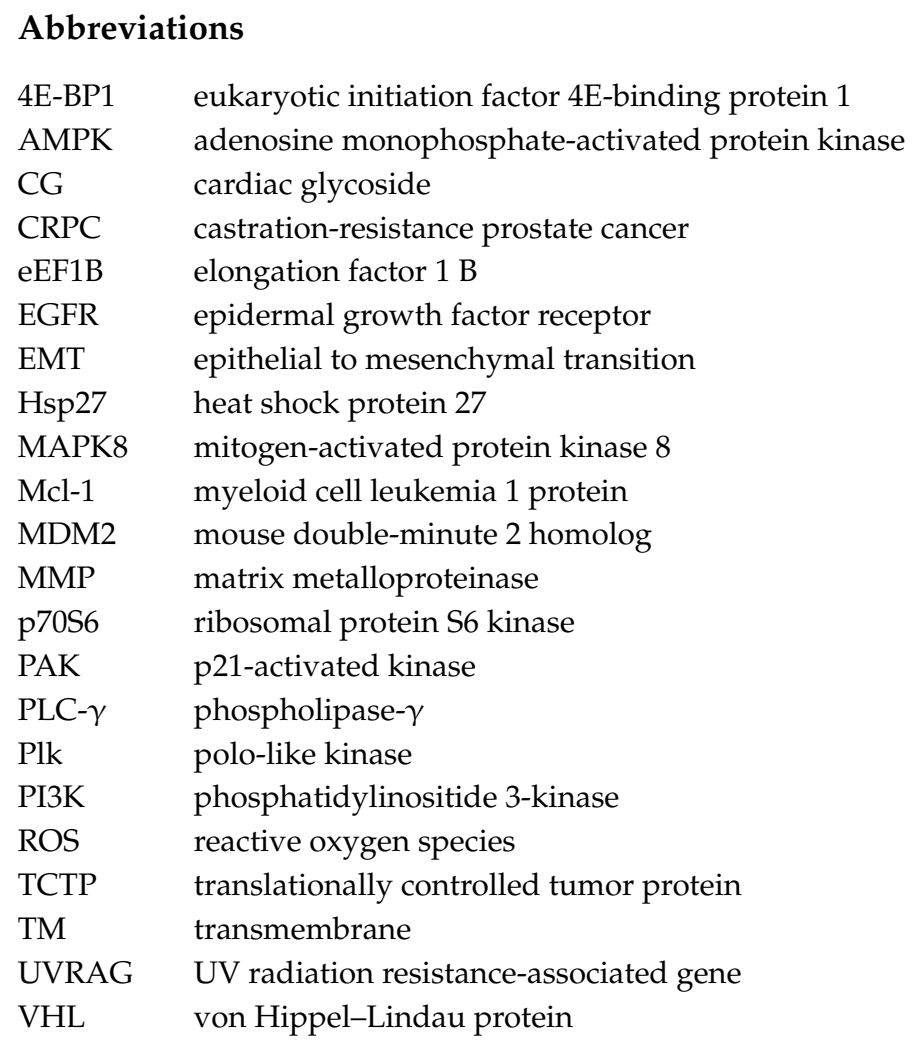

\section{References}

1. Skou, J.C. The influence of some cations on an adenosine triphosphatase from peripheral nerves. Biochim. Biophys. Acta 1957, 23, 394-401. [CrossRef]

2. Erecinska, M.; Silver, I.A. Atp and brain function. J. Cereb. Blood Flow Metab. 1989, 9, 2-19. [CrossRef] [PubMed]

3. Feraille, E.; Doucet, A. Sodium-potassium-adenosinetriphosphatase-dependent sodium transport in the kidney: Hormonal control. Physiol. Rev. 2001, 81, 345-418. [CrossRef] [PubMed]

4. Friedrich, B.; Matskevich, I.; Lang, F. Cell volume regulatory mechanisms. Contrib. Nephrol. 2006, 152, 1-8. [PubMed]

5. Brioudes, F.; Thierry, A.M.; Chambrier, P.; Mollereau, B.; Bendahmane, M. Translationally controlled tumor protein is a conserved mitotic growth integrator in animals and plants. Proc. Natl. Acad. Sci. USA 2010, 107, 16384-16389. [CrossRef] [PubMed] 
6. Bommer, U.A.; Thiele, B.J. The translationally controlled tumour protein (TCTP). Int. J. Biochem. Cell Biol. 2004, 36, 379-385. [CrossRef]

7. Jorgensen, P.L.; Hakansson, K.O.; Karlish, S.J. Structure and mechanism of Na,K-ATPase: Functional sites and their interactions. Annu. Rev. Physiol. 2003, 65, 817-849. [CrossRef] [PubMed]

8. Kaplan, J.H. Biochemistry of Na,K-ATPase. Annu. Rev. Biochem. 2002, 71, 511-535. [CrossRef] [PubMed]

9. Hardwicke, P.M.; Freytag, J.W. A proteolipid associated with Na,K-ATPase is not essential for ATPase activity. Biochem. Biophys. Res. Commun. 1981, 102, 250-257. [CrossRef]

10. Reinhard, L.; Tidow, H.; Clausen, M.J.; Nissen, P. $\mathrm{Na}^{+}, \mathrm{K}^{+}$-ATPase as a docking station: Protein-protein complexes of the $\mathrm{Na}^{+}, \mathrm{K}^{+}$-ATPase. Cell. Mol. Life Sci. 2013, 70, 205-222. [CrossRef] [PubMed]

11. Blanco, G.; Mercer, R.W. Isozymes of the Na-K-ATPase: Heterogeneity in structure, diversity in function. Am. J. Physiol. 1998, 275, F633-F650. [CrossRef] [PubMed]

12. Mobasheri, A.; Avila, J.; Cozar-Castellano, I.; Brownleader, M.D.; Trevan, M.; Francis, M.J.; Lamb, J.F.; Martin-Vasallo, P. $\mathrm{Na}^{+}, \mathrm{K}^{+}$-ATPase isozyme diversity; comparative biochemistry and physiological implications of novel functional interactions. Biosci. Rep. 2000, 20, 51-91. [CrossRef] [PubMed]

13. Geering, K. The functional role of beta subunits in oligomeric P-type ATPases. J. Bioenerg. Biomembr. 2001, 33, 425-438. [CrossRef] [PubMed]

14. Rajasekaran, S.A.; Palmer, L.G.; Quan, K.; Harper, J.F.; Ball, W.J., Jr.; Bander, N.H.; Peralta Soler, A.; Rajasekaran, A.K. Na,K-ATPase $\beta$-subunit is required for epithelial polarization, suppression of invasion, and cell motility. Mol. Biol. Cell 2001, 12, 279-295. [CrossRef] [PubMed]

15. Geering, K. Functional roles of Na,K-ATPase subunits. Curr. Opin. Nephrol. Hypertens. 2008, 17, $526-532$. [CrossRef] [PubMed]

16. Blaustein, M.P. Endogenous ouabain: Role in the pathogenesis of hypertension. Kidney Int. 1996, 49, 1748-1753. [CrossRef] [PubMed]

17. Kjeldsen, K.; Braendgaard, H.; Sidenius, P.; Larsen, J.S.; Norgaard, A. Diabetes decreases $\mathrm{Na}^{+}-\mathrm{K}^{+}$pump concentration in skeletal muscles, heart ventricular muscle, and peripheral nerves of rat. Diabetes 1987, 36, 842-848. [CrossRef] [PubMed]

18. Schoner, W.; Scheiner-Bobis, G. Endogenous and exogenous cardiac glycosides: Their roles in hypertension, salt metabolism, and cell growth. Am. J. Physiol.-Cell Physiol. 2007, 293, C509-C536. [CrossRef] [PubMed]

19. Tao, Q.F.; Hollenberg, N.K.; Graves, S.W. Sodium pump inhibition and regional expression of sodium pump alpha-isoforms in lens. Hypertension 1999, 34, 1168-1174. [CrossRef] [PubMed]

20. Haas, M.; Wang, H.; Tian, J.; Xie, Z. Src-mediated inter-receptor cross-talk between the $\mathrm{Na}^{+} / \mathrm{K}^{+}$-ATPase and the epidermal growth factor receptor relays the signal from ouabain to mitogen-activated protein kinases. J. Biol. Chem. 2002, 277, 18694-18702. [CrossRef] [PubMed]

21. Haas, M.; Askari, A.; Xie, Z. Involvement of Src and epidermal growth factor receptor in the signal-transducing function of $\mathrm{Na}^{+} / \mathrm{K}^{+}$-ATPase. J. Biol. Chem. 2000, 275, 27832-27837. [CrossRef] [PubMed]

22. Yuan, Z.; Cai, T.; Tian, J.; Ivanov, A.V.; Giovannucci, D.R.; Xie, Z. Na/K-ATPase tethers phospholipase C and IP3 receptor into a calcium-regulatory complex. Mol. Biol. Cell 2005, 16, 4034-4045. [CrossRef] [PubMed]

23. Zhou, X.; Jiang, G.; Zhao, A.; Bondeva, T.; Hirszel, P.; Balla, T. Inhibition of Na,K-ATPase activates PI3 kinase and inhibits apoptosis in LLc-PK1 cells. Biochem. Biophys. Res. Commun. 2001, 285, 46-51. [CrossRef] [PubMed]

24. Yenofsky, R.; Bergmann, I.; Brawerman, G. Messenger rna species partially in a repressed state in mouse sarcoma ascites cells. Proc. Natl. Acad. Sci. USA 1982, 79, 5876-5880. [CrossRef] [PubMed]

25. Hsu, Y.C.; Chern, J.J.; Cai, Y.; Liu, M.; Choi, K.W. Drosophila TCTP is essential for growth and proliferation through regulation of drheb gtpase. Nature 2007, 445, 785-788. [CrossRef] [PubMed]

26. Yarm, F.R. Plk phosphorylation regulates the microtubule-stabilizing protein TCTP. Mol. Cell. Biol. 2002, 22, 6209-6221. [CrossRef] [PubMed]

27. MacDonald, S.M.; Rafnar, T.; Langdon, J.; Lichtenstein, L.M. Molecular identification of an IgE-dependent histamine-releasing factor. Science 1995, 269, 688-690. [CrossRef] [PubMed]

28. Tuynder, M.; Fiucci, G.; Prieur, S.; Lespagnol, A.; Geant, A.; Beaucourt, S.; Duflaut, D.; Besse, S.; Susini, L.; Cavarelli, J.; et al. Translationally controlled tumor protein is a target of tumor reversion. Proc. Natl. Acad. Sci. USA 2004, 101, 15364-15369. [CrossRef] [PubMed] 
29. Jung, J.; Kim, H.Y.; Kim, M.; Sohn, K.; Kim, M.; Lee, K. Translationally controlled tumor protein induces human breast epithelial cell transformation through the activation of Src. Oncogene 2011, 30, 2264-2274. [CrossRef] [PubMed]

30. Nagano-Ito, M.; Ichikawa, S. Biological effects of mammalian translationally controlled tumor protein (TCTP) on cell death, proliferation, and tumorigenesis. Biochem. Res. Int. 2012, 2012, 204960. [CrossRef] [PubMed]

31. Bae, S.Y.; Kim, H.J.; Lee, K.J.; Lee, K. Translationally controlled tumor protein induces epithelial to mesenchymal transition and promotes cell migration, invasion and metastasis. Sci. Rep. 2015, 5, 8061. [CrossRef] [PubMed]

32. Kim, M.; Min, H.J.; Won, H.Y.; Park, H.; Lee, J.C.; Park, H.W.; Chung, J.; Hwang, E.S.; Lee, K. Dimerization of translationally controlled tumor protein is essential for its cytokine-like activity. PLoS ONE 2009, 4, e6464. [CrossRef] [PubMed]

33. Chen, S.H.; Wu, P.S.; Chou, C.H.; Yan, Y.T.; Liu, H.; Weng, S.Y.; Yang-Yen, H.F. A knockout mouse approach reveals that TCTP functions as an essential factor for cell proliferation and survival in a tissue- or cell type-specific manner. Mol. Biol. Cell 2007, 18, 2525-2532. [CrossRef] [PubMed]

34. Yang, Y.; Yang, F.; Xiong, Z.; Yan, Y.; Wang, X.; Nishino, M.; Mirkovic, D.; Nguyen, J.; Wang, H.; Yang, X.F. An n-terminal region of translationally controlled tumor protein is required for its antiapoptotic activity. Oncogene 2005, 24, 4778-4788. [CrossRef] [PubMed]

35. Liu, H.; Peng, H.W.; Cheng, Y.S.; Yuan, H.S.; Yang-Yen, H.F. Stabilization and enhancement of the antiapoptotic activity of mcl-1 by TCTP. Mol. Cell. Biol. 2005, 25, 3117-3126. [CrossRef] [PubMed]

36. Baylot, V.; Katsogiannou, M.; Andrieu, C.; Taieb, D.; Acunzo, J.; Giusiano, S.; Fazli, L.; Gleave, M.; Garrido, C.; Rocchi, P. Targeting TCTP as a new therapeutic strategy in castration-resistant prostate cancer. Mol. Ther. J. Am. Soc. Gene Ther. 2012, 20, 2244-2256. [CrossRef] [PubMed]

37. Chen, Y.; Fujita, T.; Zhang, D.; Doan, H.; Pinkaew, D.; Liu, Z.; Wu, J.; Koide, Y.; Chiu, A.; Lin, C.C.; et al. Physical and functional antagonism between tumor suppressor protein p53 and fortilin, an anti-apoptotic protein. J. Biol. Chem. 2011, 286, 32575-32585. [CrossRef] [PubMed]

38. Amson, R.; Pece, S.; Lespagnol, A.; Vyas, R.; Mazzarol, G.; Tosoni, D.; Colaluca, I.; Viale, G.; Rodrigues-Ferreira, S.; Wynendaele, J.; et al. Reciprocal repression between p53 and TCTP. Nat. Med. 2011, 18, 91-99. [CrossRef] [PubMed]

39. Funston, G.; Goh, W.; Wei, S.J.; Tng, Q.S.; Brown, C.; Tong, L.J.; Verma, C.; Lane, D.; Ghadessy, F. Binding of translationally controlled tumour protein to the N-terminal domain of HDM2 is inhibited by nutlin-3. PLoS ONE 2012, 7, e42642. [CrossRef] [PubMed]

40. Kim, M.J.; Kwon, J.S.; Suh, S.H.; Suh, J.K.; Jung, J.; Lee, S.N.; Kim, Y.H.; Cho, M.C.; Oh, G.T.; Lee, K. Transgenic overexpression of translationally controlled tumor protein induces systemic hypertension via repression of $\mathrm{Na}^{+}, \mathrm{K}^{+}$-ATPase. J. Mol. Cell. Cardiol. 2008, 44, 151-159. [CrossRef] [PubMed]

41. Kim, M.J.; Lyu, J.; Sohn, K.B.; Kim, M.; Cho, M.C.; Joo, C.K.; Lee, K. Over-expression of translationally controlled tumor protein in lens epithelial cells seems to be associated with cataract development. Transgenic Res. 2009, 18, 953-960. [CrossRef] [PubMed]

42. Wu, H.; Gong, W.; Yao, X.; Wang, J.; Perrett, S.; Feng, Y. Evolutionarily conserved binding of translationally controlled tumor protein to eukaryotic elongation factor 1b. J. Biol. Chem. 2015, 290, 8694-8710. [CrossRef] [PubMed]

43. Katsogiannou, M.; Andrieu, C.; Baylot, V.; Baudot, A.; Dusetti, N.J.; Gayet, O.; Finetti, P.; Garrido, C.; Birnbaum, D.; Bertucci, F.; et al. The functional landscape of hsp27 reveals new cellular processes such as DNA repair and alternative splicing and proposes novel anticancer targets. Mol. Cell. Proteom. 2014, 13, 3585-3601. [CrossRef] [PubMed]

44. Zhang, D.; Li, F.; Weidner, D.; Mnjoyan, Z.H.; Fujise, K. Physical and functional interaction between myeloid cell leukemia 1 protein (mcl1) and fortilin. The potential role of mcl1 as a fortilin chaperone. J. Biol. Chem. 2002, 277, 37430-37438. [CrossRef] [PubMed]

45. Jung, J.; Kim, M.; Kim, M.J.; Kim, J.; Moon, J.; Lim, J.S.; Kim, M.; Lee, K. Translationally controlled tumor protein interacts with the third cytoplasmic domain of Na,K-ATPase alpha subunit and inhibits the pump activity in hela cells. J. Biol. Chem. 2004, 279, 49868-49875. [CrossRef] [PubMed]

46. Gachet, Y.; Tournier, S.; Lee, M.; Lazaris-Karatzas, A.; Poulton, T.; Bommer, U.A. The growth-related, translationally controlled protein $\mathrm{p} 23$ has properties of a tubulin binding protein and associates transiently with microtubules during the cell cycle. J. Cell Sci. 1999, 112 Pt 8, 1257-1271. [PubMed] 
47. Chen, K.; Chen, S.; Huang, C.; Cheng, H.; Zhou, R. Tctp increases stability of hypoxia-inducible factor 1alpha by interaction with and degradation of the tumour suppressor vhl. Biol. Cell 2013, 105, 208-218. [CrossRef] [PubMed]

48. Ewing, R.M.; Chu, P.; Elisma, F.; Li, H.; Taylor, P.; Climie, S.; McBroom-Cerajewski, L.; Robinson, M.D.; O'Connor, L.; Li, M.; et al. Large-scale mapping of human protein-protein interactions by mass spectrometry. Mol. Syst. Biol. 2007, 3, 89. [CrossRef] [PubMed]

49. Kim, M.; Jung, J.; Lee, K. Roles of erk, pi3 kinase, and plc-gamma pathways induced by overexpression of translationally controlled tumor protein in hela cells. Arch. Biochem. Biophys. 2009, 485, 82-87. [CrossRef] [PubMed]

50. Yudowski, G.A.; Efendiev, R.; Pedemonte, C.H.; Katz, A.I.; Berggren, P.O.; Bertorello, A.M. Phosphoinositide-3 kinase binds to a proline-rich motif in the $\mathrm{Na}^{+}, \mathrm{K}^{+}$-ATPase alpha subunit and regulates its trafficking. Proc. Natl. Acad. Sci. USA 2000, 97, 6556-6561. [CrossRef] [PubMed]

51. Tian, J.; Cai, T.; Yuan, Z.; Wang, H.; Liu, L.; Haas, M.; Maksimova, E.; Huang, X.Y.; Xie, Z.J. Binding of Src to $\mathrm{Na}^{+} / \mathrm{K}^{+}$-ATPase forms a functional signaling complex. Mol. Biol. Cell 2006, 17, 317-326. [CrossRef] [PubMed]

52. Blaustein, M.P. Physiological effects of endogenous ouabain: Control of intracellular $\mathrm{Ca}^{2+}$ stores and cell responsiveness. Am. J. Physiol. 1993, 264, C1367-C1387. [CrossRef] [PubMed]

53. Herrera, V.L.; Chobanian, A.V.; Ruiz-Opazo, N. Isoform-specific modulation of $\mathrm{Na}^{+}, \mathrm{K}^{+}-\mathrm{ATPase}$ alpha-subunit gene expression in hypertension. Science 1988, 241, 221-223. [CrossRef] [PubMed]

54. Yuan, C.M.; Manunta, P.; Hamlyn, J.M.; Chen, S.; Bohen, E.; Yeun, J.; Haddy, F.J.; Pamnani, M.B. Long-term ouabain administration produces hypertension in rats. Hypertension 1993, 22, 178-187. [CrossRef] [PubMed]

55. Goto, A.; Yamada, K.; Yagi, N.; Yoshioka, M.; Sugimoto, T. Physiology and pharmacology of endogenous digitalis-like factors. Pharmacol. Rev. 1992, 44, 377-399. [PubMed]

56. Iwamoto, T.; Kita, S.; Zhang, J.; Blaustein, M.P.; Arai, Y.; Yoshida, S.; Wakimoto, K.; Komuro, I.; Katsuragi, T. Salt-sensitive hypertension is triggered by $\mathrm{Ca}^{2+}$ entry via $\mathrm{Na}^{+} / \mathrm{Ca}^{2+}$ exchanger type- 1 in vascular smooth muscle. Nat. Med. 2004, 10, 1193-1199. [CrossRef] [PubMed]

57. Zhang, S.H.; Reddick, R.L.; Piedrahita, J.A.; Maeda, N. Spontaneous hypercholesterolemia and arterial lesions in mice lacking apolipoprotein e. Science 1992, 258, 468-471. [CrossRef] [PubMed]

58. Cho, Y.; Maeng, J.; Ryu, J.; Shin, H.; Kim, M.; Oh, G.T.; Lee, M.Y.; Lee, K. Hypertension resulting from overexpression of translationally controlled tumor protein increases the severity of atherosclerosis in apolipoprotein e knock-out mice. Transgenic Res. 2012, 21, 1245-1254. [CrossRef] [PubMed]

59. Delamere, N.A.; Tamiya, S. Expression, regulation and function of Na,K-ATPase in the lens. Prog. Retinal Eye Res. 2004, 23, 593-615. [CrossRef] [PubMed]

60. Davies, P.D.; Duncan, G.; Pynsent, P.B.; Arber, D.L.; Lucas, V.A. Aqueous humour glucose concentration in cataract patients and its effect on the lens. Exp. Eye Res. 1984, 39, 605-609. [CrossRef]

61. Duncan, G.; Bushell, A.R. Ion analyses of human cataractous lenses. Exp. Eye Res. 1975, 20, $223-230$. [CrossRef]

62. Karlsson, J.O.; Andersson, M.; Kling-Petersen, A.; Sjostrand, J. Proteolysis in human lens epithelium determined by a cell-permeable substrate. Investig. Ophthalmol. Vis. Sci. 1999, 40, 261-264.

63. Gupta, P.D.; Johar, K.; Vasavada, A. Causative and preventive action of calcium in cataracto-genesis. Acta Pharmacol. Sin. 2004, 25, 1250-1256. [PubMed]

64. Klein, B.E.; Klein, R.; Jensen, S.C.; Linton, K.L. Hypertension and lens opacities from the beaver dam eye study. Am. J. Ophthalmol. 1995, 119, 640-646. [CrossRef]

65. Bommer, U.A.; Vine, K.L.; Puri, P.; Engel, M.; Belfiore, L.; Fildes, K.; Batterham, M.; Lochhead, A.; Aghmesheh, M. Translationally controlled tumour protein TCTP is induced early in human colorectal tumours and contributes to the resistance of HCT116 colon cancer cells to 5-fu and oxaliplatin. Cell Commun. Signal. 2017, 15, 9. [CrossRef] [PubMed]

66. Kaarbo, M.; Storm, M.L.; Qu, S.; Waehre, H.; Risberg, B.; Danielsen, H.E.; Saatcioglu, F. TCTP is an androgen-regulated gene implicated in prostate cancer. PLoS ONE 2013, 8, e69398. [CrossRef] [PubMed]

67. Acunzo, J.; Baylot, V.; So, A.; Rocchi, P. TCTP as therapeutic target in cancers. Cancer Treat. Rev. 2014, 40, 760-769. [CrossRef] [PubMed]

68. Xie, Z.; Askari, A. Na ${ }^{+} / \mathrm{K}^{+}$-ATPase as a signal transducer. Eur. J. Biochem. 2002, 269, 2434-2439. [CrossRef] [PubMed] 
69. Sato, K.; Nagao, T.; Iwasaki, T.; Nishihira, Y.; Fukami, Y. Src-dependent phosphorylation of the EGF receptor Tyr-845 mediates Stat-p21waf1 pathway in A431 cells. Genes Cells 2003, 8, 995-1003. [CrossRef] [PubMed]

70. Yeatman, T.J. A renaissance for Src. Nat. Rev. Cancer 2004, 4, 470-480. [CrossRef] [PubMed]

71. Jorissen, R.N.; Walker, F.; Pouliot, N.; Garrett, T.P.; Ward, C.W.; Burgess, A.W. Epidermal growth factor receptor: Mechanisms of activation and signalling. Exp. Cell Res. 2003, 284, 31-53. [CrossRef]

72. Batzer, A.G.; Rotin, D.; Urena, J.M.; Skolnik, E.Y.; Schlessinger, J. Hierarchy of binding sites for Grb2 and Shc on the epidermal growth factor receptor. Mol. Cell. Biol. 1994, 14, 5192-5201. [CrossRef] [PubMed]

73. Hallberg, B.; Rayter, S.I.; Downward, J. Interaction of Ras and Raf in intact mammalian cells upon extracellular stimulation. J. Biol. Chem. 1994, 269, 3913-3916. [PubMed]

74. Kumar, R.; Gururaj, A.E.; Barnes, C.J. P21-activated kinases in cancer. Nat. Rev. Cancer 2006, 6, 459-471. [CrossRef] [PubMed]

75. Wells, A.; Grandis, J.R. Phospholipase C-gamma1 in tumor progression. Clin. Exp. Metastasis 2003, 20, 285-290. [CrossRef] [PubMed]

76. Nagase, H.; Visse, R.; Murphy, G. Structure and function of matrix metalloproteinases and TIMPs. Cardiovasc. Res. 2006, 69, 562-573. [CrossRef] [PubMed]

77. Rowe, R.G.; Weiss, S.J. Breaching the basement membrane: Who, when and how? Trends Cell Biol. 2008, 18, 560-574. [CrossRef] [PubMed]

78. Impola, U.; Jeskanen, L.; Ravanti, L.; Syrjanen, S.; Baldursson, B.; Kahari, V.M.; Saarialho-Kere, U. Expression of matrix metalloproteinase (MMP)-7 and MMP-13 and loss of MMP-19 and p16 are associated with malignant progression in chronic wounds. Br. J. Dermatol. 2005, 152, 720-726. [CrossRef] [PubMed]

79. Sternlicht, M.D.; Bissell, M.J.; Werb, Z. The matrix metalloproteinase stromelysin-1 acts as a natural mammary tumor promoter. Oncogene 2000, 19, 1102-1113. [CrossRef] [PubMed]

80. Fanjul-Fernandez, M.; Folgueras, A.R.; Cabrera, S.; Lopez-Otin, C. Matrix metalloproteinases: Evolution, gene regulation and functional analysis in mouse models. Biochim. Biophys. Acta 2010, 1803, 3-19. [CrossRef] [PubMed]

81. Levine, B.; Klionsky, D.J. Development by self-digestion: Molecular mechanisms and biological functions of autophagy. Dev. Cell 2004, 6, 463-477. [CrossRef]

82. Glick, D.; Barth, S.; Macleod, K.F. Autophagy: Cellular and molecular mechanisms. J. Pathol. 2010, $221,3-12$. [CrossRef] [PubMed]

83. Codogno, P.; Meijer, A.J. Autophagy and signaling: Their role in cell survival and cell death. Cell Death Differ. 2005, 12 (Suppl. 2), 1509-1518. [CrossRef] [PubMed]

84. Bae, S.Y.; Byun, S.; Bae, S.H.; Min, D.S.; Woo, H.A.; Lee, K. TPT1 (tumor protein, translationally-controlled 1) negatively regulates autophagy through the BECN1 interactome and an MTORC1-mediated pathway. Autophagy 2017, 13, 820-833. [CrossRef] [PubMed]

85. Yoon, T.; Kim, M.; Lee, K. Inhibition of Na,K-ATPase-suppressive activity of translationally controlled tumor protein by sorting nexin 6. FEBS Lett. 2006, 580, 3558-3564. [CrossRef] [PubMed]

86. Liu, Y.; Levine, B. Autosis and autophagic cell death: The dark side of autophagy. Cell Death Differ. 2015, 22, 367-376. [CrossRef] [PubMed]

87. Bjorkoy, G.; Lamark, T.; Brech, A.; Outzen, H.; Perander, M.; Overvatn, A.; Stenmark, H.; Johansen, T. P62/sqstm1 forms protein aggregates degraded by autophagy and has a protective effect on huntingtin-induced cell death. J. Cell Biol. 2005, 171, 603-614. [CrossRef] [PubMed]

88. Pankiv, S.; Clausen, T.H.; Lamark, T.; Brech, A.; Bruun, J.A.; Outzen, H.; Overvatn, A.; Bjorkoy, G.; Johansen, T. P62/sqstm1 binds directly to Atg8/LC3 to facilitate degradation of ubiquitinated protein aggregates by autophagy. J. Biol. Chem. 2007, 282, 24131-24145. [CrossRef] [PubMed]

89. Pattingre, S.; Tassa, A.; Qu, X.; Garuti, R.; Liang, X.H.; Mizushima, N.; Packer, M.; Schneider, M.D.; Levine, B. Bcl-2 antiapoptotic proteins inhibit beclin 1-dependent autophagy. Cell 2005, 122, 927-939. [CrossRef] [PubMed]

90. Wei, Y.; Pattingre, S.; Sinha, S.; Bassik, M.; Levine, B. Jnk1-mediated phosphorylation of bcl-2 regulates starvation-induced autophagy. Mol. Cell 2008, 30, 678-688. [CrossRef] [PubMed]

91. Liang, C.; Feng, P.; Ku, B.; Dotan, I.; Canaani, D.; Oh, B.H.; Jung, J.U. Autophagic and tumour suppressor activity of a novel beclin1-binding protein uvrag. Nat. Cell Biol. 2006, 8, 688-699. [CrossRef] [PubMed] 
92. Dong, X.; Yang, B.; Li, Y.; Zhong, C.; Ding, J. Molecular basis of the acceleration of the GDP-GTP exchange of human ras homolog enriched in brain by human translationally controlled tumor protein. J. Biol. Chem. 2009, 284, 23754-23764. [CrossRef] [PubMed]

93. Peng, T.; Golub, T.R.; Sabatini, D.M. The immunosuppressant rapamycin mimics a starvation-like signal distinct from amino acid and glucose deprivation. Mol. Cell. Biol. 2002, 22, 5575-5584. [CrossRef] [PubMed]

94. Zhou, J.; Tan, S.H.; Nicolas, V.; Bauvy, C.; Yang, N.D.; Zhang, J.; Xue, Y.; Codogno, P.; Shen, H.M. Activation of lysosomal function in the course of autophagy via mtorc1 suppression and autophagosome-lysosome fusion. Cell Res. 2013, 23, 508-523. [CrossRef] [PubMed]

95. Chen, K.; Huang, C.; Yuan, J.; Cheng, H.; Zhou, R. Long-term artificial selection reveals a role of TCTP in autophagy in mammalian cells. Mol. Biol. Evolut. 2014, 31, 2194-2211. [CrossRef] [PubMed]

(C) 2018 by the authors. Licensee MDPI, Basel, Switzerland. This article is an open access article distributed under the terms and conditions of the Creative Commons Attribution (CC BY) license (http:/ / creativecommons.org/licenses/by/4.0/). 